\title{
Rozwój technik łączenia materiałów - spawanie tworzyw polimerowych
}

\section{Development of Techniques of materials joining - welding of plastics}

\section{Streszczenie}

W artykule przedstawiono dynamicznie rozwijające się metody i techniki łączenia elementów z tworzyw polimerowych. Zgrzewanie i spawanie to podstawowe techniki łączenie tworzyw termoplastycznych. Bardzo interesującymi cechami charakteryzuje się zwłaszcza zgrzewanie laserowe.

Słowa kluczowe: łączenie, spawanie, zgrzewanie, tworzywa polimerowe

\section{Abstract}

The article presents a dynamically developing methods and techniques of plastic elements joining. Welding is the basic technique of thermoplastics junction. Laser welding is characterized by very interesting features.

Keywords: joining, welding, plastics

\section{Wstęp}

Na podstawie przeglądu tematyki poruszanej na łamach Przeglądu Spawalnictwa stwierdzić należy, że tematyka łączenia tworzyw polimerowych pojawia się niezwykle rzadko. Tworzywa polimerowe, ze względu na atrakcyjne właściwości, w wielu zastosowaniach wypierają klasyczne, metalowe, materiały konstrukcyjne. Ze względu na dość złożone, zmienne wraz z temperaturą właściwości, łączenie elementów z tworzyw polimerowych nie jest łatwym procesem. W związku ze zwiększającą się ilością dostępnych na rynku tworzyw polimerowych, a także rosnącymi wymaganiami odnośnie efektów ich łączenia, doskonalone są już znane techniki łączenia i jednocześnie powstają nowe. Wobec powyższego postanowiono opracować artykuł przedstawiający tematykę łączenia tworzyw polimerowych.

W przypadku tworzyw polimerowych, dokładnie tak jak w przypadku metali wyróżniamy kilka metod łączenia. Metody łączenia tworzyw polimerowych są analogiczne do stosowanych w przypadku łączenia metali. Do najpopularniejszych z nich zaliczyć należy spawanie i zgrzewanie, następnie klejenie i laminowanie. W każdej z tych metod wyróżnić możemy zróżnicowane techniki [1].

\section{Zasady doboru metody łączenia tworzyw polimerowych}

Wybór metody łączenia elementów z tworzyw polimerowych jest uzależniony od ich struktury i właściwości termicznych, ale wpływ na to mają również zastosowane w tworzywie polimerowym dodatki np.: plastyfikatory, antypireny, napeł- niacze i inne. Tworzywa termoplastyczne (o budowie liniowej i rozgałęzionej) bardzo dobrze łączą się metodami spawania i zgrzewania. Tworzywa chemo- i termoutwardzalne (usieciowane) nie łączą się poprzez zgrzewanie czy spawanie, można je łączyć technikami klejenia i laminowania. Do tworzyw łatwo się spajających (spawalnych i zgrzewalnych) zaliczamy polichlorek winylu PVC (plastyfikowany - miękki - PVC-P i twardy PVC), polipropylen PP, polietylen małej PE-LD i dużej gęstości PE-HD, poliamid PA, polistyren PS, kopolimer akrylonitrylo-butadienowo-styrenowy ABS, polimetakrylan metylu PMMA (szkło organiczne - plexi), poliwęglan PC i inne. Techniką klejenia można łączyć tworzywa polarne, np. PVC (plastyfikowany i twardy), PS, ABS, PMMA. Natomiast PE czy PP bez specjalnych zabiegów przygotowujących powierzchnię nie nadają się do klejenia.

\section{Spawanie i zgrzewanie tworzyw polimerowych}

Zasadnicza różnica pomiędzy spawaniem a zgrzewaniem polega, na stosowaniu lub nie dodatkowego materiału łączącego. Jeżeli stosujemy dodatkowy materiał łączący to mamy do czynienia ze spawaniem, jeżeli nie, to ze zgrzewaniem $[1 \div 3]$. W metodzie spawania tworzyw wyróżniamy trzy techniki a mianowicie: spawanie ręczne wahadłowe i ciągnione oraz mechaniczne spawanie ekstruzyjne. W metodach ręcznych, tak jak w spawaniu metali, rowek spawalniczy wypełniamy pojedynczymi ściegami aż do uzyskania spoiny o właściwych wymiarach. Ilość wymaganych ście-

Prof. nzw. dr hab. inż. Tomasz Rydzkowski - Uniwersytet Warmińsko Mazurski w Olsztynie, dr inż. Iwona Michalska-Pożoga - Politechnika Koszalińska.

Autor korespondencyjny/Corresponding author. tomasz.rydzkowski@uwm.edu.pl 
gów jest uzależniona od grubości łączonych elementów oraz średnicy pręta używanego do spawania. W spawaniu ekstruzyjnym wykorzystując specjalne urządzenie wykonuje się tylko jeden ścieg, tj. ścieg wypełniający. Aby uzyskać trwałe połączenie należy łączony i dodatkowy materiał podgrzać powyżej temperatury plastyczności. W takim stanie tworzywa stają się miękkie, a ich rozgałęziona budowa umożliwia połączenie się łańcuchów polimerowych na poziomie cząsteczkowym i powstanie trwałych połączeń pomiędzy łączonym materiałem i materiałem dodatkowym. Zakres temperatury łączenia jest zwykle dość wąski i jest uzależniony od rodzaju materiału. Niedotrzymanie reżimu temperaturowego prowadzi do uzyskania nietrwałych połączeń (gdy temperatura złącza była zbyt niska), lub nawet do destrukcji termicznej tworzywa (gdy temperatura przekroczy temperaturę rozkładu tworzywa), co również prowadzi do uzyskania spoiny o niewłaściwych cechach. Tworzywa polimerowe generalnie charakteryzują się małym współczynnikiem przewodzenia ciepła, uzyskanie właściwej temperatury i uplastycznienie warstwy materiału o odpowiedniej grubości jest zatem długotrwałe. Dodatkowo mierzenie temperatury w momencie spawania jest bardzo trudne, w związku z czym uzyskanie właściwej spoiny wymaga dużego doświadczenia.

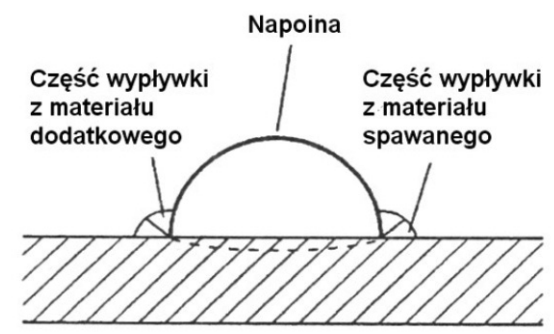

Rys. 1. Napoina z wypływkami [1]

Fig. 1. The deposit weld with outflows [1]

Jednym ze zjawisk towarzyszących spawaniu elementów z tworzyw polimerowych jest powstawanie wypływki materiału łączonego i dodatkowego (rys. 1). Wypływki składają się w części z materiału łączonego i z materiału dodatkowego. Pojawienie się podczas spawania odpowiedniej wypływki jest sygnałem świadczącym o uzyskaniu właściwych warunków do łączenia, co w efekcie prowadzi do uzyskania złącza o odpowiednich właściwościach.

Podczas spawania tworzyw stosuje się materiał dodatkowy (ten sam rodzaj tworzywa co materiał łączony), a dodatkowo obydwa materiały powinny charakteryzować się podobną budową cząsteczkową, o czym może świadczyć wskaźnik szybkości płynięcia deklarowany przez producenta. Materiał dodatkowy zwykle występuje w postaci prętów o określonej długości lub ciągłego pręta nawiniętego na bęben. Kształt przekroju prętów jest uzależniony od przeznaczenia. Najczęściej występują pręty spawalnicze o przekroju kołowym i trójkątnym, typowy zakres średnic to 2 do $5 \mathrm{~mm}$. Spotyka się również pręty o przekroju owalnym i w postaci płaskich beleczek. W metodzie spawania ekstruzyjnego (rys. 2) jako materiału dodatkowego czasem nie stosuje się prętów. Przy dużych wydajnościach spawania materiał dodatkowy może być w postaci granulatu (dużo tańszy od prętów), jest uplastyczniany w małym, zwykle mobilnym ekstruderze-wytłaczarce i podawany systemem kanałów do głowicy, zwanej butem spawalniczym (rys. 3). But spawalniczy kieruje strumień tworzywa, dociska go do uprzednio rozgrzanych łączonych elementów i dodatkowo formuje lico spoiny. Cechą charakterystyczną dla spawania ekstruzyjnego jest układanie tylko jednego ściegu wypełniającego, przy klasycznym spawaniu prętami układa się zwykle kilka ściegów, aż do wypełnienia rowka spawalniczego.

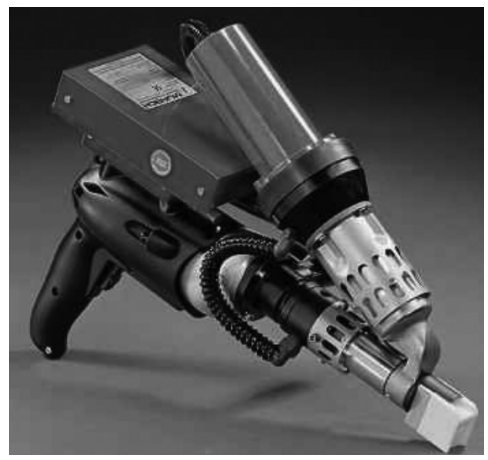

Rys. 2. Ręczna spawarka ekstruzyjna, w prawym dolnym narożniku widoczna biała głowica - but spawalniczy [4]

Fig. 2. Hand plastic welding gun, right lower corner - white welding shoe [4]

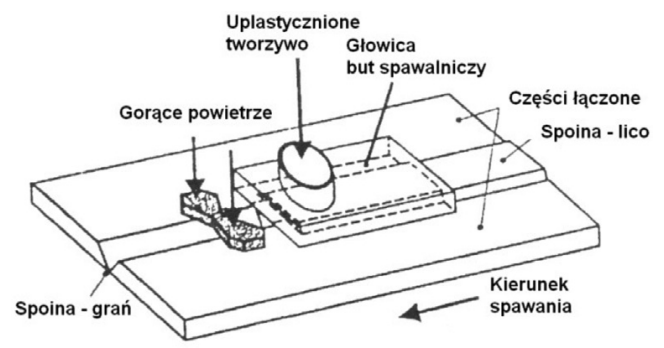

Rys. 3. Spawanie ekstruzyjne [1]

Fig. 3. Extrusion welding [1]

Zgrzewanie jest równie dynamicznie rozwijającą się techniką łączenia tworzyw polimerowych. Jak było wspomniane na początku niniejszego materiału, zgrzewanie to proces łączenia co najmniej dwóch materiałów, bez użycia spoiwa - materiału dodatkowego, ale z zastosowaniem docisku. Najczęściej zgrzewane są rury wykonane z PE-HD i profile okienne z PVC, zgrzewać jednak można również PP i inne termoplasty. Charakterystyczne wypływki w postaci okrągłych wałeczków powstają tylko w przypadku zgrzewania PE, inne tworzywa posiadają wypływki innych kształtów. Jedną z popularniejszych technik w tej metodzie jest zgrzewanie doczołowe. Uzyskiwanie właściwej temperatury elementów łączonych może odbywać się różnymi technikami. Dostarczenie energii niezbędnej do uplastycznienia tworzywa może odbywać się poprzez kontakt z elementem grzejnym lub poprzez dyssypację energii mechanicznej przez tarcie elementów zgrzewanych (zgrzewanie tarciowe).

W budowie instalacji rurowych często stosuje się zgrzewanie elektrooporowe, wymaga ono jednak stosowania kosztownych kształtek z wtopionymi elementami grzejnymi (rys. 4). Kształtki wytwarza się techniką wtryskiwania, w ich wnętrzu znajdują się odpowiednie uzwojenia z drutu oporowego, na zewnątrz wyprowadzone są styki, przez które w trakcie zgrzewania zasila się elementy grzejne. Konstrukcja kształtek przewiduje zwykle dwie gorące i trzy zimne strefy. Strefy gorące doprowadzają do uplastycznienia tworzywa (polimery podczas ogrzewania zwiększają swoją objętość, co zapewnia uzyskanie szczelnych połączeń), natomiast strefy zimne ograniczają możliwość wypłynięcia stopionego tworzywa poza strefy gorące, co zabezpiecza przed dostaniem się tworzywa w światło połączenia oraz zapewnia wysoką estetyczność uzyskiwanych połączeń. Łączenie elementów tworzyw polimerowych odbywa się w temperaturach znacznie niższych niż zgrzewanie metali. W związku z tym połączenia zgrzewane są wrażliwe na wszelkie zanieczyszczenia powierzchni łączonych. Kształtki dostarczane są zwykle w hermetycznych opakowaniach, są z nich wyjmowane bezpośrednio przed użyciem. Szczególna uwagę należy poświęcić końcówkom rur, wymagają one usunięcia zewnętrznej, utlenionej warstwy tworzywa. Uzyskanie właściwego połączenia zgrzewanych elektrooporowo elementów wymaga precyzyjnego ustawienia parametrów procesu (zwłaszcza temperatury i czasu zgrzewania). Nowoczesne kształtki mają przewidziane 
układy wspomagające automatyzację procesu zgrzewania, zwykle polega to na umieszczeniu we wnętrzu kształtek mikrowyłączników, podczas uplastyczniania tworzywo zwiększa swą objętość, gdy jest całkowicie uplastycznione przerywa obwód elektryczny zasilający strefy grzejne kształtki. Kształtki do zgrzewania elektrooporowego są oznaczane kodami paskowymi, zgrzewarki wyposażone są w skanery odczytujące z kodów parametry zgrzewania.

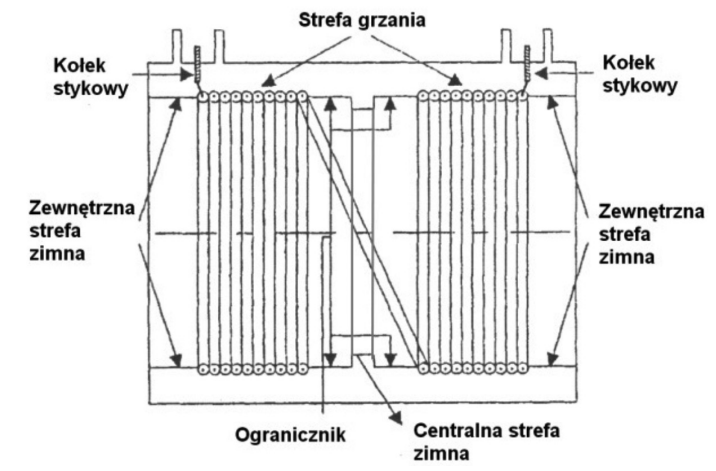

Rys. 4. Schemat mufy do zgrzewania elektrooporowego [1] Fig. 4. Scheme of coupling unit for electrofusion [1]

Kolejną interesującą techniką zgrzewania instalacji rurowych jest zgrzewanie polifuzyjne [7]. Podobnie jak zgrzewanie elektrooporowe polega na uplastycznianiu odpowiednich powierzchni rur i specjalnych kształtek za pomocą elektrycznych elementów grzejnych i następnie ich precyzyjnym połączeniu, wsunięciu końcówek rur w otwory kształtek (rys. 5). W tej technice w kształtkach nie ma elementów grzejnych. Do ogrzewania łączonych elementów stosuje się elektryczne, wielorazowe kształtki grzejne odpowiednio dopasowane do otworów kształtek i końcówek rur. Technika ta wymaga precyzyjnego kontrolowania parametrów zgrzewania, ich dotrzymanie gwarantuje uzyskanie właściwego połączenia. Połączenia są trwałe i estetyczne.

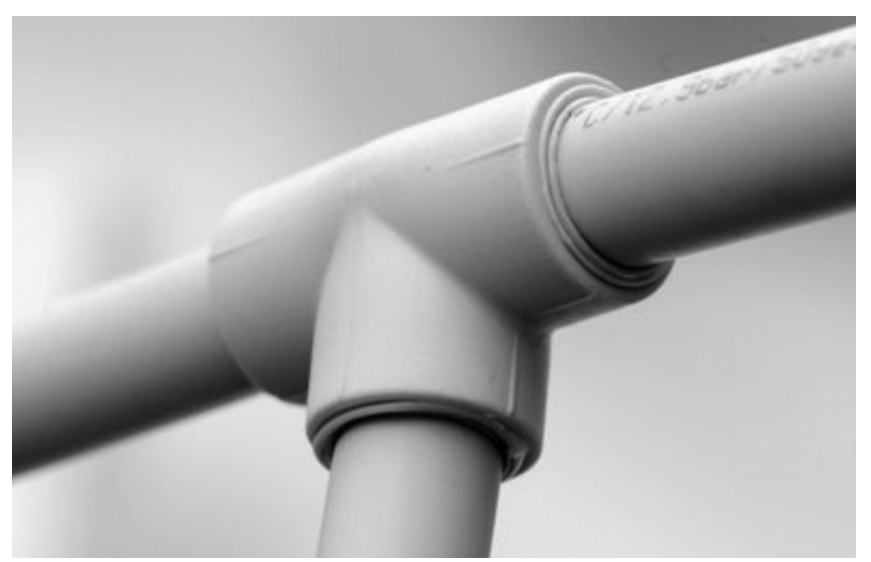

Rys. 5. Fragment instalacji zgrzewanej polifuzyjnie [7]

Fig. 5. Part of installation joined by socket fusion fittings [7]

Odmienne techniki wykorzystuje się do uzyskiwania trwałych i szczelnych połączeń podczas zgrzewania folii. Zgrzewanie folii może być problematyczne z powodu ich niewielkiej grubości, wynoszącej zwykle ok. $2 \mathrm{~mm}$ w związku z tym bardzo ławo o przegrzanie i uzyskanie zgrzewu o złych parametrach. Podczas zgrzewania folii temperatura uzyskiwana jest poprzez zastosowanie gorącego powietrza, druga technika to zastosowanie elektrycznych elementów grzejnych, zwykle rolek lub klina. Po ogrzaniu do momentu uplastycznienia folie są mechanicznie lub ręcznie dociskane przez określony czas zależny od grubości i rodzaju materiału. W przypadku połączeń o podwyższonej odpowiedzialności (pokrycia dachowe lub geomembrany mogilników czy składowisk odpadów) stosuje się ciekawą technikę umożliwiającą dość łatwe sprawdzenie szczelności uzyskanego zgrzewu. Wykonuje się dwa równoległe zgrzewy (rys. 6), a po zakończeniu łączenia na krańcach łączonych folii, z jednej ze stron, pomiędzy dwoma zgrzewani, wprowadza specjalny króciec przyłączeniowy. Następnie na krańcach prostopadłych do linii łączenia folii wykonuje się kolejne zgrzewy, dzięki temu uzyskujemy zamkniętą przestrzeń z doprowadzonym króćcem. Do tej przestrzeni wprowadzamy powietrze i zamykamy króciec. Krócieć może być wyposażony w manometr dzięki, któremu obserwujemy zmiany ciśnienia co pozwala szybko stwierdzić czy wykonane połączenie jest szczelne.

a)

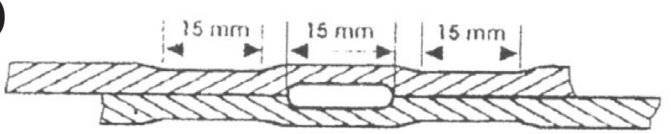

Zgrzew na zakladkę $z$ kanałem kontrolnym

b)

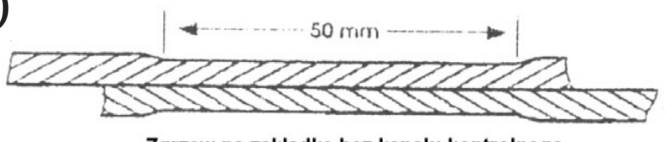

Zgrzew na zakładke bez kanalu kontrolnego

Rys. 6. Zgrzewanie geomembran foliowych: a) zgrzew z kanałem kontrolnym, b) zgrzew bez kanału kontrolnego [1]

Fig. 6. Welding of geomembrane films: a) the seal with the control panel, b) the seal without control channel [1]

Podstawowymi parametrami procesu spawania i zgrzewania są: temperatura, docisk i czas. Stabilność temperatury determinuje jakość i wytrzymałość uzyskanego połączenia. Czynnikiem grzewczym jest gorące powietrze, które może być zastąpione, znanymi ze spawania metali, gazami ochronnymi (argon, hel), ciepło do uplastycznienia materiału dodatkowego może pochodzić z grzejników elektrycznych. W przypadku zgrzewania źródeł ciepła może być więcej: gorące powietrze, grzejniki elektryczne, energia mechaniczna zamieniana w ciepło poprzez tarcie oraz coraz częściej stosowana wiązka promieni lasera.

Coraz bardziej popularne staje się łączenie elementów z tworzyw polimerowych z wykorzystaniem energii wiązki laserowej. Zwykle opisując tę metodę mówi się o spawaniu tworzyw laserem, co jednak nie jest określeniem właściwym, ze względu na brak stosowania materiału dodatkowego (elektrody). Dlatego też tę metodę łączenia tworzyw należy zaliczać do zgrzewania. Tu należy jednak zauważyć, że powstają techniki przybliżające zgrzewanie laserowe do spawania (lub lutowania), polegają one na nakładaniu w miejscu planowanego połączenia specjalnych warstw absorbujących promieniowanie i zamieniających je w ciepło niezbędne do uplastycznienia. Uplastycznienie tworzyw polimerowych wiązką promieniowania laserowego

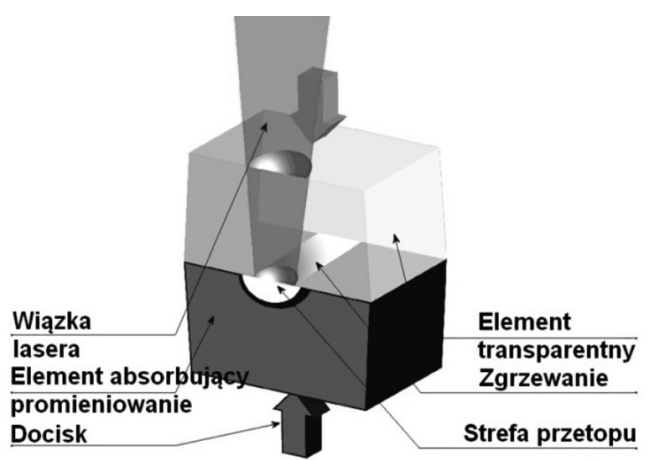

Rys. 7. Zgrzewanie laserowe przenikające [5]

Fig. 7. Penetrating laser welding [5] 
nie jest zadaniem prostym. Dla promieniowania elektromagnetycznego część tworzyw jest przezroczysta i nie następuje w nich absorpcja promieniowania, tworzywo nie nagrzewa się i w efekcie nie uzyskuje się połączenia. W tym aspekcie istotne są składniki dodatkowe wprowadzane do polimerów, a szczególnie barwniki i napełniacze zwiększające absorpcję promieniowania laserowego [5].

W tej metodzie wyróżnić możemy zasadniczo dwie techniki: zgrzewanie doczołowe i zgrzewanie przenikające. W tej pierwszej, wiązka promieniowania ma za zadanie nadtopić krawędzie łączonych elementów, które następnie są do siebie dociskane $z$ odpowiednią siłą. W drugiej natomiast mamy zwykle do czynienia z dwoma rodzajami materiału: materiałem transparentnym (przepuszczającym promienie laserowe) i materiałem absorbującym promieniowanie (rys. 7). Można w ten sposób łączyć elementy z takiego samego tworzywa np. polimetakrylan metylu (PMMA) przezroczysty z barwionym lub napełnionym, co ma miejsce $\mathrm{w}$ samochodowych reflektorach, gdzie łączymy przezroczyste, bezbarwne lub zabarwione, klosze reflektorów z nieprzezroczystymi korpusami (rys. 8). Technika ta ma szczególne zastosowanie w dynamicznie rozwijających się precyzyjnych technikach: mikroelektronice i innych zaawansowanych technologiach, w tym w medycynie i technice kosmicznej [6]. Do licznych zalet tej techniki zaliczyć można: bardzo precyzyjne, niewielkie złącza, minimalną strefę wpływu temperatury i zmian struktury materiału poza samym złączem, możliwość łączenia elementów o mikro-rozmiarach, bardzo dużą powtarzalność jakości złącza, brak wypływki, czy bardzo dużą estetykę złącza.

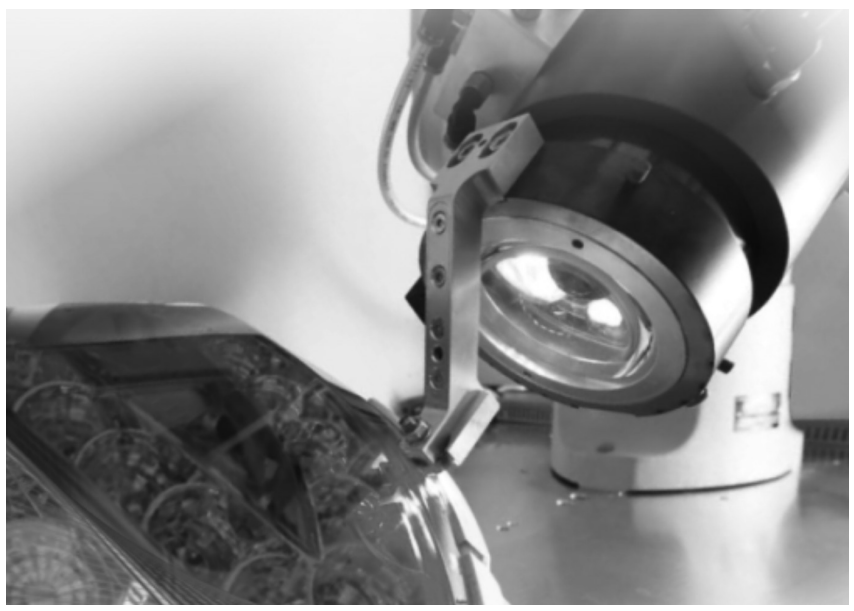

Rys. 8. Laserowe zgrzewanie reflektora samochodowego [6] Fig. 8. Laser welding of car headlight [6]

\section{Podsumowanie}

Rozwój technik wytwarzania a zwłaszcza bardzo dynamiczny postęp w mikro- i nanotechnikach, przyczynia się do powstawania nowych materiałów i technik ich łączenia. Coraz częściej klasyczne materiały konstrukcyjne zastępowane są nowoczesnymi tworzywami polimerowymi, kompozytami czy materiałami ceramicznymi. Wszystkie one wymagają specyficznych technik spajania. W takim świetle rozwijanie obecnych i powstawanie nowych technik łączenia materiałów ma przed sobą jeszcze wiele poważnych wyzwań.

\section{Literatura}

[1] Jasiulek P.: Łączenie tworzyw sztucznych metodami spawania, zgrzewania, klejenia i laminowania, Wydawnictwo KaBe, Krosno 2006.

[2] Pilarczyk J., Pilarczyk J.: Spawanie i napawanie elektryczne metali, Wydawnictwo "Śląsk" Spółka z o.o., Katowice 1996.

[3] Poradnik Inżyniera. Spawalnictwo. WNT. Warszawa 2005.

[4] http://www.amargo.pl/zgrzewarki.htm.
[5] http://www.konstrukcjeinzynierskie.pl/2009/39-fragmenty/flipiecsierpien2009/171-przezroczyste-spawanie-tworzyw-sztucznych.html.

[6] http://www.lpkf-laserwelding.com/index.htm.

[7] http://pl.wavin.com/web/systemy/woda-pitna-1/instalacje-wewnetrzne.htm. 